\title{
Social entrepreneurship as a collaborative practice: Literature review and research agenda
}

\section{Sunna Kovanen ${ }^{1}$}

\begin{abstract}
Purpose: The aim of this article is, firstly, to explore and structure the emerging research on collaboration in social entrepreneurship, and secondly to tackle the identified gaps in the literature with a research agenda based on the communities and networks of practice theory. Methodology: The article relies on a systematic literature review, which summarizes the existing evidence base and critically evaluates major theoretical approaches. The analytical focus is on ambiguity and scales of collaboration. Findings: Three main research strands have been identified: first, community and public sector collaboration focusing on the participatory initiation of services by local communities; second, collaboration for resources and employment focusing on power relations between established organizations; and third, network- and micro-level collaboration focusing on collaborative governance of complex networks. A vaguely contextualized and non-critical approach to social entrepreneurship remains prominent; however, recent studies on community and network collaboration present nuanced approaches to scalarity and ambiguity. Implications for theory and practice: Existing research could benefit from explicit and broader theorization of collaboration, the analysis of ambiguous experiences and contexts and attending to the interplay between daily practices and larger-scale institutional change. The paper presents a compiled reference base and gives directions about future research and practice re-thinking social enterprise as a collaborative endeavor. Originality and value: The article contributes to social entrepreneurship studies by structuring the field and enhancing critical theory on the topic.
\end{abstract}

Keywords: social entrepreneurship, social enterprise, cooperation, collaboration, communities of practice, networks of practice

1 Sunna Kovanen, MSc., Doctoral Researcher, Leibniz-Institute for Regional Geography, Leipzig Schongauerstrasse 9, 04328 Leipzig, Germany, e-mail: s_kovanen@leibniz-ifl.de (ORCID: https://orcid.org/0000-0003-1777-3328). 


\section{INTRODUCTION}

As critique on the discourse of individual social entrepreneurs increases, some recent scholarship has turned the focus on social entrepreneurship as a collaborative endeavor (de Bruin, Shaw, \& Lewis, 2017; Montgomery, Dacin, $\&$ Dacin, 2012). Collaboration is claimed to explain both the success of some enterprises (Borzaga \& Galera, 2016) as well as the risk of the mission drift of others (Kwong, Tasavori, \& Wun-mei Cheung, 2017). Studying collaborative processes has deconstructed the myth of heroic leadership (Stubbs \& Vidović, 2017), has revealed its reliance on peer-networks and grassroots mobilizing (Richter, 2018), and has underlined the interdependency of collaboration and ethics in economy (Bachnik \& Szumniak-Samolej, 2017). This emergent scholarship relies on a myriad of theory fields with established traditions as well as diverse new conceptualizations and applications. The aim of this study is to support the prospective research endeavors by providing an overview of state of the art and increasing conceptual transparency between different approaches (Tregear, 2011). This is done firstly through conducting a systematic literature review (SLR) on collaboration in social entrepreneurship, with the focus on Europe. Secondly, a new research agenda with the communities and networks of practice theories (Brown \& Duguid, 2001; Wenger, 2008) is suggested. The review answers the following research questions (RQ):

RQ1: What do we know empirically about collaboration and which theories have been applied in social entrepreneurship research?

RQ2: How have ambiguity and scales of collaboration been approached so far? $R Q 3:$ What are prospective directions for future research?

It will be argued that an emerging paradigm shift towards collaborative processes can be identified and empirical knowledge exists especially in the fields of village-based engagement and institutional resource collaboration. However, there is room to improve the political, analytical, and geographical rigor of the research, and this article suggests approaching the gap with a practice approach.

Although early social entrepreneurship literature has received criticism for its "monological" (Cho, 2008, p. 36) and "neoliberal" (Mauksch, 2012, p. 157) approach, it still features among the most cited works. Thus, a critical review of the knowledge base is required to overcome this inheritance. Social entrepreneurship has been defined as an individual skill and character (Christmann, 2014; Forster \& Grichnik, 2013; Thompson, 2008), driven by leaders with "a passion...and a strong ethical fiber" (Mair \& Martí, 2006, p. 38). 
Dey and Steyaert (2010) describe this discourse as a messianistic celebration of managerial thought, which renders exploitative structures as simple marketbased problems (Dacin, Dacin, \& Matear, 2010) and people dealing with them as passive victims. Equally criticized has been the frequent reliance on anecdotal empiric work with idiosyncratic case studies (Mair \& Martí, 2006), often derived from private foundations (Nicholls, 2006; Olinsson, 2017) who have their own business-case in celebrating social entrepreneurship. Even though the quality of the empirical work has been increasing, social entrepreneurship is still usually studied from the perspective of one single leader (Dey \& Teasdale, 2016; Muñoz, 2010) and with interviews conducted with the leaders only (Kimmitt \& Muñoz, 2018; Shaw \& Carter, 2007; Tracey, Phillips, \& Haugh, 2005).

Therefore, this review aims at expanding this canon by approaching social entrepreneurship as a collaborative, ambiguous, and multi-scalar endeavor. Focus on ambiguity in collaboration serves to reveal whether the calls to broaden the rational and overly positive research approach have been applied (Dart, 2004; Dey \& Steyaert, 2012). The second focus is inspired by the critique on inadequate analyses of the spatiality of social entrepreneurship (Amin, Cameron, \& Hudson, 20020; Bacq \& Janssen, 2011; Muñoz, 2010). This approach contributes to the studies on social enterprise networks (Dufays \& Huybrechts, 2014; Littlewood \& Khan, 2018) without focusing on them explicitly, as qualified work on this field has already been conducted. Furthermore, studies on networks tend to rely strongly on social network theory (Littlewood \& Khan, 2018) and focus on organizations' and individuals' network constellations instead of on their actual making. Therefore, a precise focus on collaboration covering diverse theories on the field was considered relevant.

Finally, it is argued that the critical elements of the communities and networks of practice approach provide previously overlooked and underdeveloped potential for the emerging research field (Contu \& Willmott, 2003). Theory's attention to mundane collective practices and lay work helps to understand the processes and resources of social entrepreneurship, as Dacin, Dacin, and Matear (2010, p. 201) have proposed in their classic article, but remaining in their empirics on the level of "Skoll's proven track record."

The article is structured as follows. The next section describes the selection and analysis process of the material. The three following sections present the content of the review grouped into three major strands of research: The first section presents research on Community and public sector collaboration (21 articles). The second section discusses Collaboration for resources and employment (15 articles), and the third tackles research 
on Network- and micro-level collaboration (10 articles). Each begins with a figure summarizing the empirical results, in order to support reading and to provide a collective reference base for the results. The figures contain, in summary, the main drivers, outcomes, hindrances, practices of collaboration identified within each strand. The overall results on collaboration are summarized in the section six. The seventh section presents the communities and networks of practice literature and proposes research questions based on four selected concepts within the theory. The article ends with a summary of the contribution of this text to the research field.

\section{Methodological proceeding}

The research followed the Systematic Literature Review method (SLR) according to the guidelines of Petticrew and Roberts (2007). According to the authors, an SLR is useful for synthesizing and evaluating large amounts of empirical data in a transparent manner and thus highlighting needs for further research. The research was conducted between March and April 2019, based on the following steps (Petticrew \& Roberts, 2006).

1) Defining the scope and conducting the search: The articles have been sampled with the Web of Science and SCOPUS (Elsevier) databases, which are among the largest multidisciplinary sources in social sciences. Articles were searched with 'social AND entrepreneurship' or 'social AND enterprise' in the title and with 'collaboration,' 'cooperation,' 'collaborative' OR 'collective' in the abstract. Apart from the operators, automatic search filters were applied to limit the search to peerreviewed, English-language journal articles. The result comprised of 332 abstracts with 15 duplicates.

2) Defining inclusion and exclusion criteria: The abstracts were evaluated according to the following inclusion criteria: 1) Their main results and theoretical discussion handle collaboration. 2) Social entrepreneurship is studied as a specific and independent field, instead of, e.g. entrepreneurship education or institutional entrepreneurship. 3) Excluded were conference papers, editorial letters and book chapters, as well as articles with a focus on Bottom-of-Pyramid markets. The selection included 104 articles. As a conceptual starting point, the author refers to the definition of Phillips, Lawrence, and Hardy (2000), according to whom "collaboration involves the negotiation of roles and responsibilities in a context where no legitimate authority is sufficient to manage the situation" (p. 26), excluding purely contractual or competitive relationships.

3) Limiting the selection based on quality: The text of the articles was reviewed and selected with the following inclusion criteria: 1) The 
articles had a robust methodology, i.e. they described methods used, criteria of sampling, amount of data, and argumentation for the choices. 2) Empirical data is from a European or comparable context, meaning that some articles (5) from North America, such as George and Reed (2016), from Latin American countries (Kimmitt \& Muñoz, 2018), and New Zealand (Newth, 2016) were chosen. Narrowing the spatial focus helps to avoid overly generalized and universalized claims on social entrepreneurship, criticized by Dey and Steyaert (2010, p. 89). However, it recognizes the diversity of realities behind spatial categories such as 'North' and 'South,' and the relevance of lessons that European-focused knowledge may learn from those (Lewis, 2017). This final selection resulted in 41 texts. Finally, five empirical articles most cited by the systematically selected texts and eligible according to the selection criteria were added: Tracey, Phillips, and Haugh $(2005,2007)$, Shaw and Carter (2007), Jack and Anderson (2012) as well as Battilana and Dorado (2010). Thus, the total number of texts is 46.

4) Synthesizing and analyzing results: The texts were analyzed with a simplified qualitative content analysis method, according to Mayring (2010). Firstly, three different research strands were identified according to their different theoretical foundations and empirical focus. Secondly, more detailed empirical findings were identified from the whole literature base and were manually coded under seven categories describing collaboration in order to find the most supported empirical evidence. Finally, the empirical findings were linked with the specific strand, in which they were most discussed. The categories were identified with a combined inductive and deductive method. The categories of drivers, conditioning elements and practices of collaboration emerged inductively during the analysis. Drivers were mentioned as such in some texts (Smeets, 2017), but it also covers results about 'motivations' of collaboration discussed in others. Categories of hindrances, negative experiences and outcomes of collaboration emerged deductively from the overall conceptual approach on ambiguity of collaboration, and categories were combined and adjusted in the course of the analysis. In the graphics, the font size of the empirical results indicates their relative frequency in the texts. However, the categorization should not be understood as exclusive or exhaustive, but rather as an informed interpretation of the subject. Decisions on how to classify articles and evidence, which could relate to several strands or categories, have been made considering the coherence of the strands and contents as a whole. In the analyzed texts, the most frequent spatial context has been the United Kingdom (14 articles), and especially Scotland within it. Based on the applied spatial lenses (Figure 1), collaboration is most frequently observed in rural spaces and rural-urban networks ('rurban,' 3 articles) and within the community- and network collaboration strands. 


\section{Spatialities of SE collaboration}

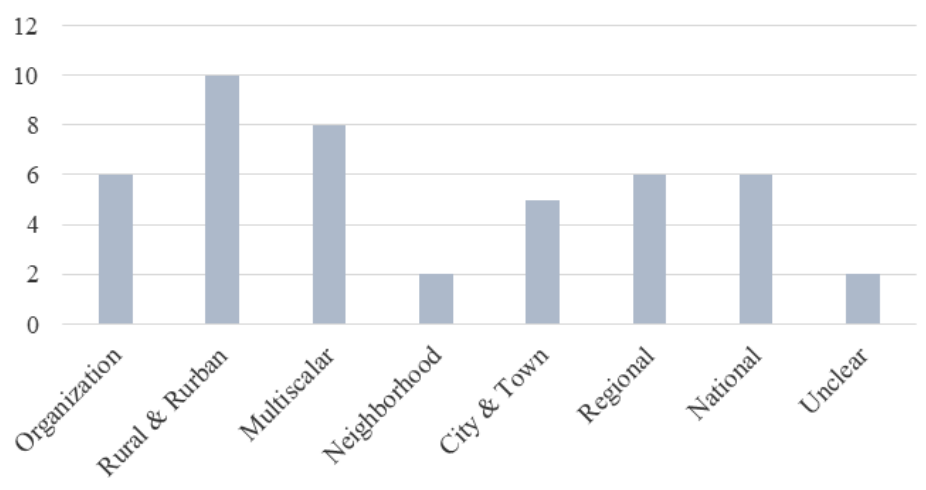

Figure 1. Spatialities of SE collaboration

Furthermore, texts with a rural, urban, or multiscalar focus commonly analyze the spatial and geographical aspects of collaborative processes, whereas in many other texts, the spatial frame is only briefly mentioned as a methodological choice. Texts with a national focus commonly analyze the institutional and political framework of collaboration. Qualitative interviews are the most used method in the sample, but ethnographic methods in diverse intensities are rather frequently used as well (Figure 2). Despite the pleas to diversify the empirical research base (Dacin, Dacin \& Matear, 2010), reliance on single case studies is still fairly common. In addition, in 11 out of 46 articles, only managers have been interviewed or surveyed.

\section{Methodological choises}

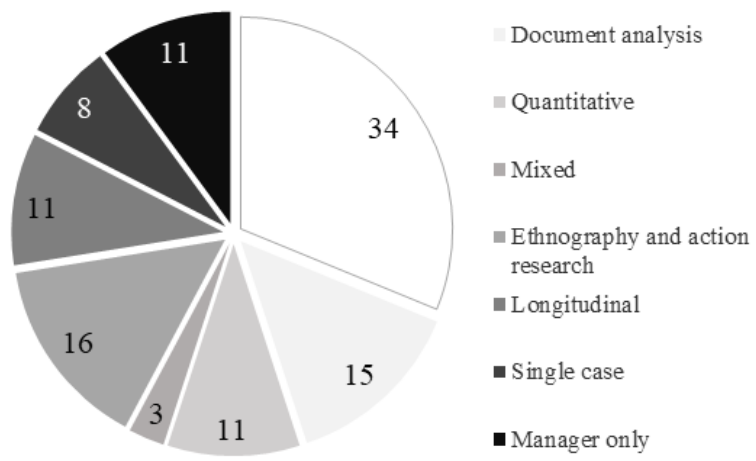

Figure 2. Methodological choices 


\section{LITERATURE REVIEW}

\section{Community and public sector collaboration}

The first presented research strand is community collaboration (Figure 3). Relying on rural sociological theories on social capital, social networks and embeddedness, the authors focus on the production of public services by and with village residents. The authors ask questions about the embeddedness of social enterprises (SE) into their communities (Vestrum, 2014), the influence of embeddedness on enterprises' social responsibility (Pret \& Carter, 2017) and about the relationships between SEs, villagers, service users, and the public sector (Borzaga \& Galera, 2016). The authors confirm that good relationships with the residents and their inclusion into the endeavor are essential for the success of establishing new service enterprises in rural areas. In addition, they emphasize the strong influence of different structures and institutions in the diverging local conditions of entrepreneurship. However, a nuanced understanding of scales tends to be lacking, especially in the conceptualization of the 'community,' and public sector collaboration is often discussed in rather simplified terms as well.

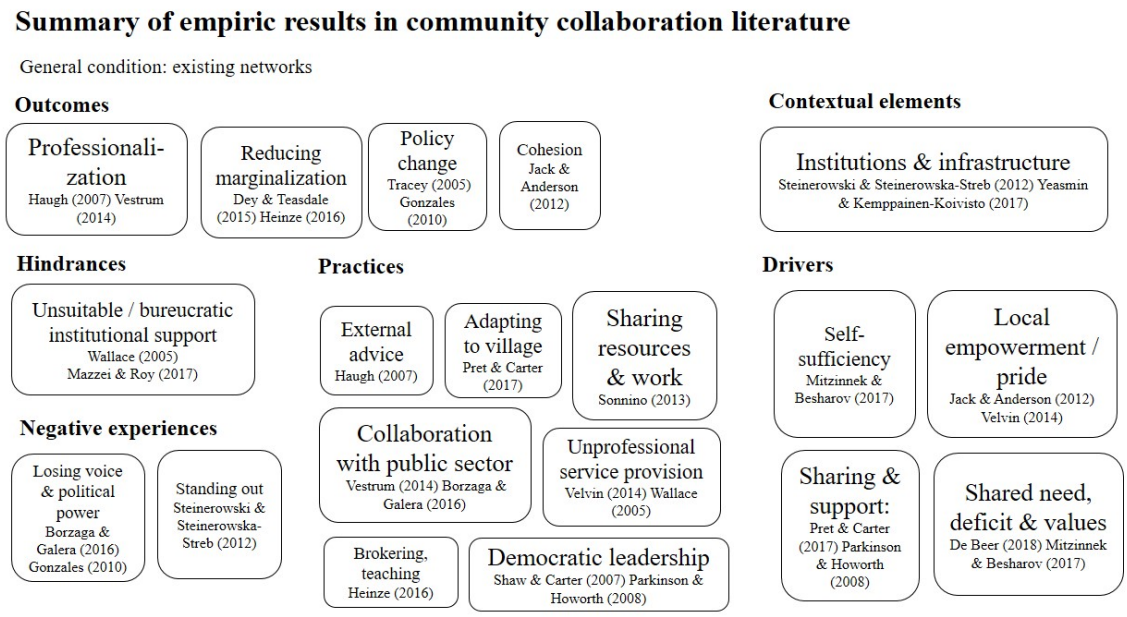

Figure 3. Community- and public sector collaboration

Typical applications of the more structural direction of this strand include those of Jack and Anderson (2002), Vestrum (2014), and Steinerowski and Steinerowska-Streb (2012). The community collaboration of SEs is described as a "rural ethos' and self-help [which] gathers people together" (Steinerowski 
\& Steinerowska-Streb, 2012, p. 173) and a process, in which "through local social contacts, entrepreneurs feel connected to and embedded in their neighbourhoods" (de Beer, 2018, p. 465). Thus, continuation of the typically local social structure is the foundation and the goal of entrepreneurship (Jack \& Anderson, 2002; Pret \& Carter, 2017). Identified drivers include pride and faith in the region as well as a genuine and shared need for a missing service (Borzaga \& Galera, 2016; Haugh, 2007; Velvin, Bjørnstad, $\&$ Krogh, 2016). After identifying the need, its fulfillment requires a certain amount of community ownership (Haugh, 2007; Vestrum, 2014). The social entrepreneur seems to maintain a central position as a teacher or 'democratic leader' of the venture, who works with and for the participants (de Beer, 2018; Dey \& Teasdale, 2016). As Parkinson and Howorth (2008, p. 298) put it, "the first person agency comes in and out of focus against the backdrop of community and collective agency." As a result, community collaboration in social entrepreneurship may enhance social cohesion and the quality of services, if the new services become better adjusted to the local conditions. Practices of collaborative service provision, in turn, tend to develop from participatory and unprofessional towards professional over time.

This research strand has, however, certain repeating problems. Firstly, the concept of community is rarely defined, but in between the lines, it usually refers to the residents of one village embedded in one, single social structure. This approach has been criticized by Gibson-Graham (2006), who provides references to a small number of articles in this review. They claim that this language provokes a "commonality of being, an ideal of sameness," which leads to "putting the cart of common substance, it would seem, before the ethical and political horse" (Gibson-Graham, 2006, p. 125). Mitzinneck and Besharov (2018), instead, take a more nuanced view in their recent article on volunteer-based energy cooperatives. The authors explore tensions emerging between cooperative members only after they have defined their shared needs. As a solution, the cooperatives either push the most controversial projects to a later stage, allow different members to support different subprojects or accept only projects enjoying a full consensus.

Secondly, studying community collaboration as a foremost local social structure presents the space of the enterprises as a self-confined and stable entity (Haugh, 2007; Shaw \& Carter, 2007; Sonnino \& Griggs-Trevarthen, 2013). For example, Steinerowski and Steinerowska-Streb $(2012$, p. 170) point out the specific challenges of rural structures for entrepreneurship, such as low accessibility and distances, but position these as a binary against an idealized 'urban' structure. This fixation on local or unified scale is fruitfully criticized by some recent studies, such as Pret and Carter (2017), who describe craft 
entrepreneurs' simultaneous embeddedness in both the villages they live in as well as in their creative and multi-scalar, professional communities.

Thirdly, the faith in local communities is especially problematic if it remains blind to the political and institutional power entangled in collaborative relationships. Authors such as Haugh (2007) and Heinze, Banaszak-Holl, and Babiak (2016) mention the involvement of local politicians in the enterprise without specifying whether it has been adequate and constructive. Furthermore, Shaw and Carter (2007) describe deficits in public service production as opportunities. According to Wallace (2005) and Parkinson and Howorth (2008), however, this language transfers corporate logic and values from national politics into the social entrepreneurship sector, disarming the actors from their radical potential and transforming them as players in neoliberal politics. Mazzei and Roy (2017) and Borzaga and Galera (2016) describe the effects of such public sector collaboration. In Borzaga and Galera's (2016, p. 39) case the "close relations that social cooperatives have established with public agencies have strongly hampered their degree of autonomy." Social cooperatives have managed to advocate a new legislation on social procurement, but the resulting regulations have pushed the cooperatives to serve the median voter and neglect the more marginal or unmet needs they originally emerged to serve. In addition, Borzaga and Galera, and Gonzales (2010) describe how corruptive relationships were overcome by the cooperatives.

To summarize, despite the forward-looking motivations of local service producers to help their peers in need, community collaboration is not entirely seen as an endogenous process. The existing infrastructure and the relationships with the public sector alike, condition social entrepreneurial processes strongly. Especially areas remote from the major markets and with market-oriented public policy exhibit less vibrant community collaboration, regardless of the pursuits of the grassroots actors (de Beer, 2018; Steinerowski \& Steinerowska-Streb, 2012). If community ventures make it through the challenging early years, they may succeed in professionalizing bottom-up production. This seems to require supportive leaders, who identify strongly with their participants. In the long run, community ownership tends to decrease together with participants' trust in public policies, if the public support system is not responsible and flexible enough to the SEs' holistic approach. Nevertheless, public sector collaboration is a frequent means to ensure the long-term operation of small, bottom-up SEs. Such institutionalized relations are at the focus in the next strand. 


\section{Collaboration for resources and employment}

The second research strand discusses collaboration for resources and employment (Figure 4), with the majority of the texts relying on organizational (Imperatori \& Ruta, 2015; Pais \& Parente, 2015) and institutional theories (George \& Reed, 2016; Huybrechts \& Nicholls,2013; Huybrechts, Nicholls \& Edinger, 2017).

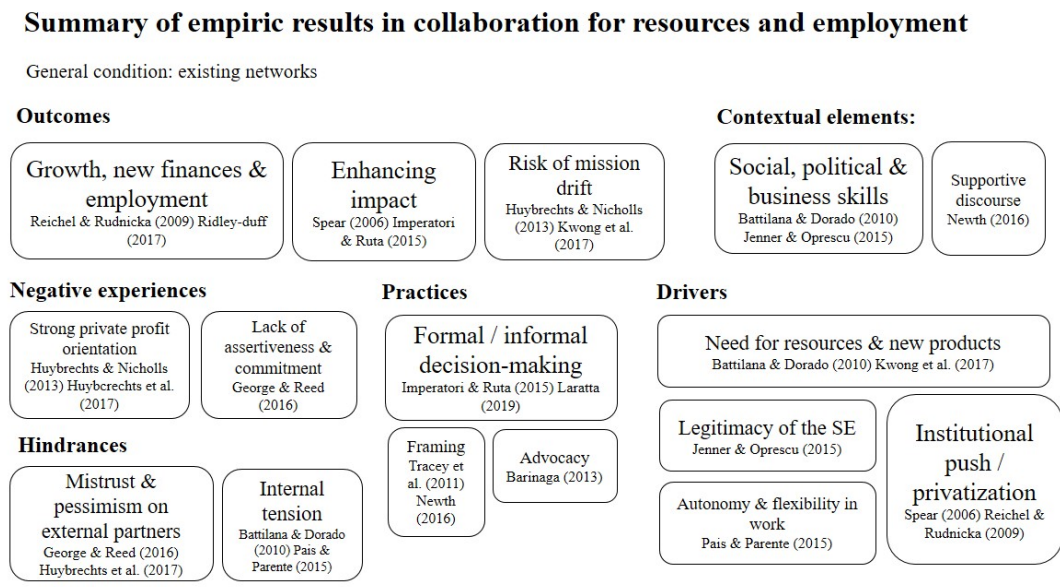

Figure 4. Summary of empiric results in collaboration for resources and employment

In general, these studies focus on the relevance of collaboration for attaining new resources for the organizations, and the management of diverging stakeholder interests in the process. The authors ask questions about the ways of organizing work and decision-making (Imperatori \& Ruta, 2015; Ridley-Duff, 2009) and about the relationships of power, autonomy, and impact between SEs and resource providers (Kwong, Tasavori, \& Wunmei Cheung, 2017; Laratta, 2009). Unlike in previous strands, the institutional literature provides an explicit theory and conceptualization of collaboration. Although this increases the analytic understanding of the ambiguity in stakeholder relations, the functional and rational foundations of the theory remain largely unquestioned. According to the results, collaboration is often driven by request for new resources, bearing a risk for conflicts of interest, especially if the partners' power positions and values differ greatly from one another. Several authors approach collaboration as a multiscalar phenomenon affected by the institutional environment, whereas micro and material spatiality remains largely unobserved. 
Most illustrative articles discussing resource relations are those of Kwong, Tasavori, and Wun-mei Cheung (2017), and Huybcrechts and Nicholls (2013). In their framing, the SEs' main driver for collaboration is to gain more resources to pursue their own ends, such as increasing their impact and influence over other actors. Resource holders, in turn, are drawn to collaborate with SEs due to the legitimacy of the latter as the representatives of their beneficiaries (Jenner, 2016; Newth, 2016). Kwong, Tasavori, and Wunmei Cheung (2017) have comprehensively described the ambiguities related to this in their interviews with nine SEs in the UK. They classify SEs' resource collaboration relationships as dormant, complementary, collaborative, and dominant. The first three types support a SE in its original mission, developing commonly between other organizations such as charities, whose values are in line with the SE. In dominant resource relationships, a public or private partner holds a crucial share of the SEs resources, and is keen on having a say about its use. The latter type of relationships bears the strongest risk of mission drift, although they may result in organizational and financial growth as well. This model is supported in its different aspects by Huybrechts and Nicholls (2013), Huybrechts, Nicholls, and Edinger (2017), Laratta (2009), and Newth (2016). The aforementioned report about "the frightening" power of supermarkets (Huybrechts, Nicholls \& Edinger, 2017, p. 597) in their collaboration with Fairtrade SEs and about the pioneering, alternative trading structures created as a response. In other cases, SEs engage in the practices of advocacy, framing and negotiation to overcome such constraints on their mission. Finally, Newth's (2016) case is an example of a collaborative resource relationship, where the resource holders' impact on the SE's work is described as "positive resistance" (p. 389), which rather "refines the innovation" than hinders it (p. 389).

Even though these findings diversify the overly positive picture presented by community collaboration scholars, several authors rely on resource dependency and related theories with a rational and functional approach (Bauer, Guzmán \& Santos, 2012; Jenner, 2016). In this line of thinking, organizations treat their partners "instrumentally and as subordinate to their individual goals but willing to engage in reciprocal favors to achieve those goals" (Dunham, 2010, p. 520). Battilana and Dorado (2010), for example, describe how workers in their 'successful' case study tried to "embarrass or convincingly threaten [micro-lenders] to pay" (p. 1424) without reflecting the ethics of such practice. This framing leaves no room to consider that the actual organizational benefit may be only realizable in an ethical and affective bond or collective identification with others (Wynne-jones, 2017). Newth (2016), instead, describes the resource-dependency-relationship as a shared sensemaking process, but a rational take prevails in his description of the 
entrepreneurs' actions. The entrepreneurs "refine their innovation to make them sufficiently attractive to institutional donors" (Newth, 2016, p. 389), never showing a hint of uncertainty or illogicality. Critical reflection, especially about the actual change-agency behind the superficial case descriptions and a few quantitative variables, is missing also in both Jenner's (2015), Reichel and Rudnicka's (2009) as well as Bauer, Guzmán, and Santos's (2012) texts.

Other authors, however, give a more socially nuanced insight, especially into the intra-organizational collaboration. For example, according to Pais and Parente (2015), Spear (2006), and Imperatori and Ruta (2015), collaboration is driven by the nature and value of the collaborative work in itself. Workers appreciate both autonomy and flexibility in their personal tasks as well as support from their team or a larger network "Thus, work becomes a central opportunity for personal growth, for taking on responsibility and for joining in and identifying with life in a community" (Imperatori \& Ruta, 2015, p. 338). Autonomy in these framings is close to the definition of Wynne-Jones (2017) as freedom "from dictates of corporate or legislative actors ... by being interdependent through cooperation" (p. 262). Furthermore, Imperatori and Ruta (2015) and Kwong, Tasavori, and Wun-mei Cheung (2017) imply that intrinsic motivations of collaboration and beneficiaries' active participation seem to be nourished by participatory and informal, rather than managerial and formal organizational practices. However, according to Battilana and Dorado (2010), informality in hiring procedures bears a risk of nepotism. Other than that, the actual organizing practices are rarely studied in depth. Pais and Parente (2015) as well as George and Reed (2016) highlight that especially the lack of assertiveness of some long-term participants may be frustrating for the more innovation-driven leaders.

Finally, in terms of scalarity, some authors blend or ignore the material, historical and institutional context of their cases altogether and thus strengthen the criticized image of social entrepreneurship as a universally successful solution (Jenner, 2016; Kwong, Tasavori, \& Wun-mei Cheung, 2017; Pais \& Parente, 2015). Therefore, this strand also has the weakest spatial analytics. Scales are addressed as different power positions between organizations with or without an institutional context but rarely as material and spatial arrangements. For example, Newth (2016) and Laratta (2009) describe how specific legislations as well as institutional and political heritages in different countries have contributed to different regional patterns of collaboration. Spear (2006) and George and Reed (2016), in turn, describe how their cases emerged in changing institutional environments due to privatization, funding cuts, or unemployment.

To summarize, ambiguity in organizational collaboration emerges from participants' various needs for resources and values of collaboration. 
Especially if a SE is dependent upon a strongly established organization, it can benefit from growth by using the resources from its partner but can run into mission drift. Articles on resource collaboration rely on and develop especially the institutional and bricolage theories, which serve the analysis of strategic inter-organizational relationships amongst institutional forces well. The authors avoid conflating local scale with successful collaboration but tend to discuss it as a straightforward and uncontextualized process, instead. An internally collaborative way of working is an important motivation in itself to participate in SEs. Meaningfulness emerges especially from the combination of supportive, participatory and flexible organizational practices, which have received, however, only limited attention in the literature so far. Many authors overlook these potentials and challenges of internal collaboration altogether in their reliance on a rational and non-relational approach to organizations. The literature on network collaboration takes this aspect a step further.

\section{Network- and micro-level collaboration}

The third research strand expands the focus from communities and organizations to regional and multi-stakeholder networks (Figure 5). These texts discuss how innovation, ecological solutions and collaborative decisionmaking are learned and spread in the fields of agriculture, music and media, and work integration.

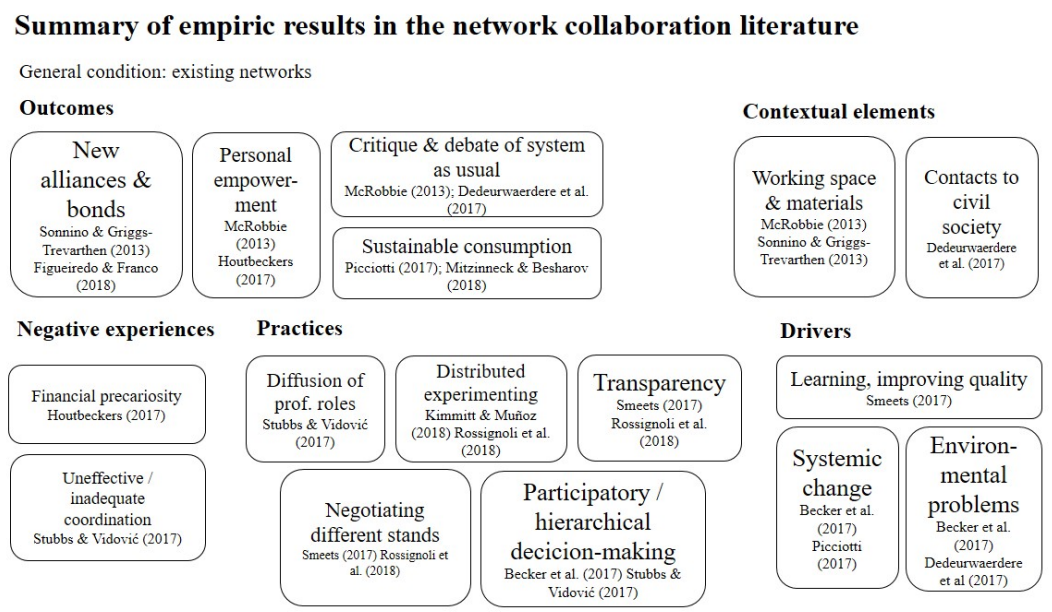

Figure 5. Summary of empiric results on network- and micro-level collaboration 
Typical questions in this section address cooperatives' impact on the region and environment (Figueiredo \& Franco, 2018; Picciotti, 2017), development and functioning of a collaborative decision-making network (Dedeurwaerdere et al., 2017; Smeets, 2017; Stubbs \& Vidović, 2017) as well as lived practices of social entrepreneurship (Houtbeckers, 2017b; McRobbie, 2013). In comparison to previous strands, these studies aim at explaining how different networks, scales and political geographies are intertwined in the collaborative processes across and beyond formal boundaries. Collaboration with civil society and the importance of information and communication technologies gain stronger attention. Both ambiguity and scales of collaboration are the most elaborately analyzed in this research strand. The accounts of power and privilege at a micro-level as well as their linkage to the possible changes in large systems, remain intriguing but are so far mostly disconnected arenas for future inquiry.

Illustrative examples of this strand are authored by Stubbs and Vidović (2017) and Rossignoli, Ricciardi, and Bonomi (2018). They describe collaboration as a "collective learning process" (Rossignoli, Ricciardi and Bonomi, 2018, p. 423) with "intrinsic fragility" (p. 427) or as a "complex relationship between a formal absence of hierarchy and the informal hierarchies" (Stubbs \& Vidović, 2017, p. 148). The identified drivers of collaboration are commonly more critical in nature, such as environmental problems or opposing injustice in larger political and economic systems. This can be traced back to the political and feminist economic theories applied in this strand (Picciotti 2017, p. 236; Stubbs \& Vidović, 2017, p. 145). Concerning outcomes of collaboration, according to Dedeurwaerdere et al. (2017), urban-rural collaboration not only enhances sustainable consumption as an individual choice, it also supports social learning about the complexities of different choices and the emergence of collective, political subjectivity. McRobbie (2013) and Houtbeckers (2017b) describe such empowering subjectivation as an embodied and emotional process, which is supported in particular by socially entrepreneurial co-working spaces for the precarious self-employed in cities. Finally, materiality of collaboration is tackled apart from the body also in technology. Smeets (2017) and Rossignoli, Ricciardi, and Bonomi (2018) describe how modern ICT has strongly supported the upscaling of SEs by providing a transparent system of handling information and payments. ICT "renders procedures modular and adjustable ... allowing a gradually wider and more diverse network of interacting actors" (Rossignoli, Ricciardi and Bonomi, 2018, p. 430).

Especially interesting in this strand are the analyses of complex collaborative decision-making processes and practices in networks. Firstly, in terms of scales, Becker, Kunze, and Vancea (2018) and Picciotti (2017), for 
example, describe SE as a bridging organization between local governments, non-profit organizations, and a multinational enterprise. Rossignoli, Ricciardi, and Bonomi (2018) and Picciotti (2017), instead, focus on Italian cooperatives, and the spreading and institutionalization of diverse, successful local practices into other locations and organizations. In some reported cases, the organization was able to push local institutional changes only thanks to the simultaneous spatial upscaling to other regions. However, these institutional changes were not provoked by the enterprises' sole agency. Rather their space of operation has co-evolved together with local, national and international regulatory frameworks (Smeets, 2017; Stubbs \& Vidović, 2017). Finally, Stubbs and Vidović (2017) and McRobbie (2013) discuss not only the spatial spread of new practices, but also the intertwining of material space with the social entrepreneurial process. For example, the initiators' passage from the cities to the countryside, Croatia's position in the EU's semi-periphery, or a city's gentrification patterns and local traditions of resistance, they all provide both preconditions and are affected by the entrepreneurial practice.

The recognition of distributed agency has important implications for the handling of internal ambiguity in collaboration as well. The studied initiatives are heterogeneous and complex, whose common strategy is yet to be defined. Their participants find common ground at best by the practices of deliberation (Smeets, 2017) and distributed experimenting (Becker, Kunze \& Vancea, 2017; Kimmitt \& Muñoz, 2018). They enable the participants to acknowledge and accept disagreements in fundamental principles, and look for the best practical solutions in a participatory decision-making process beyond diverging opinions (Becker, Kunze \& Vancea, 2017; Rossignoli, Ricciardi \& Bonomi, 2018). The theories of commons-enabling decisionmaking and collaborative learning applied by a few authors in this strand give a very advanced contribution to understanding these processes. Whereas institutional theories focus on the clash between established institutional fields, the above-mentioned theories observe how new, ethical practices and nascent, fragmented institutions emerge. However, how the practitioners experience the ambiguity of collaboration on a daily basis is grasped only by the studies with an explicit focus on feminist political theories and embodiment. McRobbie (2013) and Houtbeckers (2017b) describe the actual and potential risks of burnout among urban self-employed social entrepreneurs. Reasons are found in inadequate delegation and unequal engagement between the participants as well as in structural competition and precarity imposed on the self-employed. Stubbs and Vidović (2017), in turn, describe an initiative with an outspoken ideal of participatory structure, which in reality "reflects a kind of 'laissez-faire' approach, relying on individual responsibility as a key value" (p. 158). Thus, "the 'freedom to act' can become more a source of anxiety 
and uncertainty than a source of empowerment" (Stubbs and Vidović, 2017, p. 158). This practice unwillingly cements the position of a charismatic leader.

To summarize, local SEs may upscale into nodes in large-scale networks, create bonds between organizations with different principles and legacies, and nurture collective and empowering subjectivities. They may provide founding stones for new economic institutions of value-based, deliberative, distributed decision-making and trading, with an influence on policy. This influence results especially from their stronger outward integration instead of an inward integration into the immediate locality. However, the potential power conflicts, which innovative and radical networks may face with established and powerful institutions, could be better informed by organizational and institutional literature. In addition, such networks require committed partners who recognize the mutual interdependence and are able to handle diverging positions constructively. Especially in large networks, inadequate coordination, transparency and democracy are challenges, which some organizations have solved with ICT-based solutions. The literature drawing on feminist political economies is aware of this problem and discusses the mundane challenges of participatory work in fierce market competition. However, there is still a little discussion between the micro-level focus on embodied subjectivation and the large-scale focus on the emergence of social entrepreneurial networks. Furthermore, community collaboration literature could inform network studies about the ways and challenges of including village residents into multi-scalar networks and providing basic services on the ground.

\section{Summary of the research on collaboration}

The empiric material analyzed in this article builds a solid knowledge base about the drivers, outcomes and contexts of collaboration in social entrepreneurship. These studies have been presented along three different research strands, with their specific theories and assumptions but also significant overlaps. Community collaboration literature brings forth a thorough discussion about the emergence process of new enterprises from mainly rural, participatory initiatives in collaboration with the public sector. Whereas this early formation process is overlooked by the organizational literature on resources and employment, the latter presents a stronger understanding of the challenges of the power imbalance between established organizations. Some studies relying on the organizational literature and the majority of the third research strand, network collaboration, have explored internal tensions in complex networks. The third strand, in particular, has an emphasis on ecological production and civil-society collaboration. In 
summary, collaboration is relevant for balancing both stable institutional and resource relations as well as reaching societal change.

However, as studies tend to draw on a narrow palette of theoretical insights, much of the current research falls short of understanding ambiguity and scalarity in its field. Especially in classical sociological and entrepreneurship theories in the first and the second strand, collaboration is frequently approached as a stable structure or an external and instrumental asset of the organization itself. In the empiric findings, however, the desire to work collaboratively appeared rather as a constitutive practice of social entrepreneurship, present in all aspects of work and production. It is also a conflictive and spatially complex process. Some recent articles in community and network collaboration literature have started to address these topics (Houtbeckers, 2017b; Mitzinneck \& Besharov, 2018). The review has identified the following research gaps: Firstly, both collective practices of leadership in challenging conditions and embodied and mundane work experiences, especially those of power, privilege and failure, have been overlooked. Secondly, collaboration for resources has been treated as a challenging, but uncontextual development pattern. Thirdly, institutional change and the transformative power of SEs has been approached on a macro- and inter-organizational scale, but how this process is related to the mundane ethical negotiations and transformations internally has not been adequately researched. In the following section, the author turns to the communities and networks of practice approach as a possible way of taking the research along these lines further.

\section{RESEARCH AGENDA}

\section{Advancing the field with the communities and networks of practice approach}

Communities of practice (COP) builds a theory of learning as a joint engagement with the world, nurturing collective identification across spatial and organizational boundaries (Blackmore, 2010; Lave \& Wenger, 1991). It has been applied in research on knowledge processes in commercial organizations and to a smaller extent in civic engagement (Duguid 2008), but in the field of social entrepreneurship, it is largely an unknown terrain. However, it could help to address the above-mentioned research gaps in a number of ways. First, the CoP approach conceptualizes working, knowledge and learning as a lived experience of participation in a joint enterprise, instead of as an individual, cognitive capability, or an inevitable structuration (Tandon, 2014; 
Wenger, 2008). Therefore, according to Duguid (2008), it attends directly to the uneasy and embodied experiences of collaboration and provides a solid theoretical base to approach the phenomenon. Second, it provides a theory of how organizations and people sustain and transform themselves simultaneously, identified as the overall relevance of collaboration for SEs as well. Third, as different communities, institutions and their change are recognized along with differences in continuous practices instead of along local or organizational borders (Amin \& Roberts, 2008), it helps to observe institutional change on a micro-scale. It might direct attention beyond isomorphic pressures or social cohesion towards understanding, how such structures emerge or break in situated practice (Snyder \& Wenger, 2010). In the following, CoP and networks of practice (NoP) approaches to social entrepreneurship literature are briefly discussed, and the above-mentioned claims are elaborated further with an introduction to a new research agenda based on four selected conceptual tools of the theory: negotiation of meaning, boundary, learning trajectory and pattern. Amongst all central concepts in CoP-theory, these are both less used as well as the most appropriate lenses with which to respond to the question of this review.

CoP theory studies "learning as a social participation" (Wenger, 2008, p. 4), which takes place when people mutually engage in a joint enterprise (p. 73) in informal and voluntary groups. Members of CoPs create and rely on a history of habits, lessons and artifacts as a shared repertoire, which develops into collective identities and builds the basis for fixed institutions with their strongly codified practices (Wenger, 2008, pp. 89-91). As CoP research gives a rich account on "the process of social interaction and co-creation of meaning" (Tandon, 2014, p. 158) in "heterogeneities of proximity" (Amin \& Roberts, 2008, p. 365), it is suitable for studying collaborative and valueladen dynamics in local economies. Amin and Roberts (2008) have conducted a thorough review of CoP research, differentiating diverse CoPs based on the role of proximity in them. The article is a response to the critique of the spatial simplification and romanticization of the CoP approach, which has also inspired the concept of networks of practices. NoPs are, like CoPs, interfaces of learning but are not dependent on direct interactions or shared identity. In NoPs, collaboration takes place within the common practice repertoire, but it may be dispersed, instead of embedded, in physical closeness and brought forward by professional, transportable standards (Brown \& Duguid, 2001).

In social entrepreneurship literature, only one theoretical framing based on the CoP approach by Anita Tandon (2014) was found. Also, NoPs have been identified once by Houtbeckers (2017a) at the intersection of the fashion industry, self-employment, and upcycling. CoP theory has been commonly used in studies on social innovations and learning sustainable practices 
(Bradbury \& Middlemiss, 2015; Füg \& Ibert, 2019), which at times have SEs as cases (Bendt, Barthel, \& Colding, 2013; van der Horst, 2008). However, its frequent application in the field of organizational knowledge management has caused an impasse in the theory's development. The main focus has been on practitioners with either a strong professional identity or highly valued knowledge (Amin \& Roberts, 2008; Roberts, 2006) instead of pioneers with unconventional ideas. Furthermore, it has become commonplace to "ignore or suppress Lave and Wenger's (1991) understanding that learning processes are integral to the exercise of power and control" (Contu \& Willmott, 2003, p. 284). As SEs can be considered to integrate both socially innovative practices as well as organizational and market practices, it could provide an ideal field to combine the best of both above-mentioned applications of the CoP approach.

\section{Negotiation of a meaning: Reification and participation}

Although negotiation of meaning is a central concept in CoP theory, it has been barely applied in analysis. According to Wenger (2008), participating in joint work produces "meaning as an experience of everyday life" (pp. 52-53), which motivates and attaches people to common work. Negotiation of meaning takes place via interdependent processes of participation and reification. Reification fixes or 'objectifies' a common meaning with the help of outspoken rules, standardized methods or tools, whereas in participation, the common meanings are interpreted, persuaded, and changed (Wenger 2008, pp. 54-56). In this framing, collaboration cannot be understood as a conscious, rational strategy (Montgomery, Dacin \& Dacin, 2012), but rather as an open process and an aim in itself, constituting the foundation for learning, innovation, and motivation (Brown \& Duguid, 2001).

Furthermore, a collaborative SE is not successful merely when it scales up effectively, but also the process needs to be negotiated in a participatory manner. Studying the experiences and meaning-making behind common goals can help to understand "how affective dimensions also play a constructive role" (Wynne-Jones, 2017, p. 262) in reaching for or diverting from them. For example, the reluctance against external financing and institutionalization by many community enterprises becomes more understandable, when attending to the reification process that such funding implies. Negative experiences of bureaucratization and increasing legal responsibilities may accumulate into 'predispositions' (Roberts, 2006, p. 629), hindering learning and participation. The way these affective undertones impact collaboration could be attended with the following research questions: What meanings of work are there in social enterprises and how are they negotiated? How 
does the extent of participation and reification in collaboration relate to the participants' possibilities of learning and transformation?

\section{Boundaries}

According to Wenger (2010, p. 125), "shared practice by its very nature creates boundaries," which become interfaces of learning and contestation. Thus, attending to boundaries enables one to observe collaboration beyond the obvious organizational borders and binary categories of 'tight local' and 'distant loose' ties. Boundaries are the most explored phenomenon in social entrepreneurship research. According to Tandon (2014), sectoral boundaries (public, private, third) form a central interface in social entrepreneurship. In Bendt, Barthel, and Colding's (2013) research, in turn, boundaries emerge between and within SEs from different forms and durations of participation, such as between long-term volunteers and visitors. Also, practices of patenting design patterns and employment regulation, originally aimed at bridging gaps between sectors, may become strong boundaries themselves (Houtbeckers, 2017a).

According to the existing CoP applications in social entrepreneurship by Houtbeckers (2017b) and Tandon (2014), social entrepreneurs seem to take up the role of a boundary spanner. Boundary spanning is both an innovative and isolating practice, because spanners rarely enjoy the full recognition in any of the practice networks they engage in (Wenger, 2010). In addition, there seems to be a difference between more privileged boundary spanners, who benefit from high persistence and global networks (Houtbeckers, 2017b), and those who experience frustration due to lacking peer-support (Oreszczyn, Lane, \& Carr, 2010). CoP and social entrepreneurship research alike have had a stronger emphasis on the aforementioned type of collaboration (Richter, 2017), ignoring that practitioners may even avoid it altogether and become hostile to outsiders (Contu \& Willmott, 2003). These aspects of power and privilege have been discussed by some social entrepreneurship scholars (Barinaga, 2013), but apart from Bendt, Barthel, and Colding (2013), they have been barely explored in CoP and NoP literature. Therefore, the concept of boundary and the following research questions, inspired by Tandon (2014, pp. 162-163), might bring light to the potential internal inequalities in social entrepreneurial collaboration: What kind of boundaries of collaboration emerge in socially entrepreneurial practice? What is the relationship between institutionalized privileges and boundaries of collaboration in social entrepreneurship? How do boundaries relate to SEs' stability and change-agency? 
Learning trajectory and pattern

Wenger (2008) describes trajectory as a history of learning and identification, which accumulates in CoPs and provides an established future orientation for the newcoming participants. Patterns, in turn, refer to the spreading of practices themselves across spaces and institutional settings, forming a locally adapted but recognizable chain of practice (Wenger, 2008). Trajectories in SEs pave ways for future negotiations about acquiring new resources and members or for adopting innovative patterns. The concept of trajectory may thus help to observe, how experience becomes authority in collaborative leadership, manifesting itself in empowering and accessible as well as in discouraging and privileged positions. It is also a means to study how institutions or isomorphic forces are enforced and challenged, not only on the basis of obvious sectorial borders, but also according to the practical accumulated experience (Lave \& Wenger, 1991).

To the author's current knowledge, neither of these concepts has been applied in CoP research on social economy. Füg and Ibert (2019, p. 17), for example, rely on the concept of "(trans-) local professional community" and reveal its centrality for the "unfolding and consolidation" of an innovative approach in regional planning. However, the research focuses on an already highly professionalized field, whereas the concepts of trajectory and pattern may help to observe, how such innovative and boundary-spanning processes can or cannot emerge between different communities of professional, informal and marginal practices. In Houtbeckers' (2017a) research, for example, the "relations of non-participation are mediated by institutional arrangements" (Wenger, 2008, p. 169), and this blocked a social entrepreneur from opening up a new employment trajectory for her trainees. Such institutionally marginalized trajectories may well be discouraging for participants elaborating their future commitment in a particular SE. To explore these collaborative patterns further, the following research questions are suggested: What kind of trajectories of collaboration does social entrepreneurship nurture? In which conditions do emerging patterns of social learning and innovation challenge or become part of institutionalized market and governmental relationships?

\section{DISCUSSION}

This article presents the results of an SLR on collaboration in social entrepreneurship, and a research agenda based on CoP and NoP theories. It has analyzed peer-reviewed, empiric research reports and focused especially on the ambiguity and scalarity of collaborative processes of social 
entrepreneurship. The four concepts of the CoP approach have been discussed: negotiation of meaning, boundaries, learning trajectories and patterns, and proposed as tools to approach the processual, controversial, mundane, and transformative in joint undertakings. The article finishes by summarizing the findings and their contribution to the social entrepreneurship research field.

The request to attend to the less straightforward side of collaboration is not new. For example, in their theory of institutional collaboration, Phillips, Lawrence, and Hardy (2000, p. 27) claim that "unstructuredness" is the most important aspect of inter-organizational relations. Other early theorists, such as Muñoz (2010) and Dacin, Dacin, and Matear (2010) have encouraged scholars to focus on the geographical and challenging side of the SEs' embeddedness, including resistance to change and failure. However, until recent years, the theoretic and empiric answers have been modest. Even though the current research base is growing in amount and quality, the following aspects are still overlooked. Firstly, most of the authors neither define their conceptualization of collaboration nor reflect the scope or limits of their approach to the phenomenon clearly. This is perhaps linked to the limited application of theoretical approaches, mainly covering institutional theories, bricolage and community collaboration, whereas theories of participation, commons, social movements, governance of third sector organizations, or collaborative learning are rarely explored. Secondly, there is a need to recognize collaboration as an ambiguous and embodied process, where mundane practices, experiences and meanings of participation as well as negotiation of responsibilities play a central role. Finally, there is a need to be more contextually precise concerning the scales and the material and institutional environments of collaboration. In particular, many studies on village initiatives and local social enterprises overlook the "multiple shifting, tangled and dynamic networks connecting rural to rural and rural to urban" (Woods, 2007, p. 491) ... unevenly distributed across rural space" (Salemink, Strijker, \& Bosworth, 2017, p. 561).

CoP and NoP literature provides, instead, a promising path to the less explored terrains. Even though the original theory's contributions to the more critical questions posed in this review are not fully developed, the first attempts taken by Roberts (2006), among others, give a basis to build upon. Especially useful are her questions about power and tensions emerging from a CoP's position in the larger society and its internal expertise hierarchies. This daily, iterative work of governing has been recognized as a crucial element of just and innovative collaboration in several of the newest articles (Pret \& Carter, 2017; Richter, 2018; Rossignoli, Ricciardi, \& Bonomi, 2018; Smeets, 2017) as well as in central textbooks on social, solidarity economy and commons (Nyssens \& Petrella, 2015; Utting, 2015). CoP and NoP theories 
could contribute to this literature, especially with their attendance on how material and embodied practices enable collective subjectivation but also open it up to new impulses. Collaborative governance models and the question of ownership, in turn, have been explored in the civil society organization literature of the EMES-school (Meyer et al., 2015) and in the cooperative studies (Kasabov, 2016). These approaches deserve to be further applied and expanded with the CoP and NoP approach on the actual practices with which the different governance and ownership models are brought about.

The concepts of boundaries and trajectories, in turn, enable one to observe how practices may lay the foundations for new routines and institutions providing services and livelihoods, but also block other practices and innovations from spreading and upscaling (Tandon, 2014). This approach is suited to analyzing the mundane workings of the institutional and transformative power of collaboration between social and solidarity economic actors. CoP analysis alone is not enough to grasp the level of institutional transformation, but may provide some tools for understanding their reinforcement and rupture.

\section{CONCLUSION}

This article provides the following contributions to the field of social entrepreneurship research. It presents the state of the art empirical research on collaboration in social entrepreneurship in European and related contexts. It summarizes the evidence about elements, drivers, practices, hindrances, negative experiences, and outcomes of collaboration. By critically evaluating the current, most frequent, theoretical strands, the article provides a map to navigate the emerging paradigm shift and to develop its analytical, political, and geographical quality. It expands existing reviews and theoretical work, focusing especially on network theories. Furthermore, the article has evaluated the suitability of CoP and NoP theories and their particular concepts for this task. The article also acknowledges the limitations of the theory and methodology it relies on.

Concerning management practice, the article encourages to apply of a more critical, less functional and spatially nuanced perspective on enterprises' collaborative relations. Summarized empirical evidence on outcomes, risks and governance practices of collaboration may be a useful source for practitioners as well. Concerning theory, the possibilities of combining the research agenda with other approaches with a related ontological standpoint, such as diverse economies and commons, have been proposed. The strength of such a combination can be illustrated by naming 
two premises, which these theories hold in common. Firstly, that individual agency and creativity is embedded in and enabled only by collective, emotionally supportive, and critical undertakings (Gibson-Graham, 2006; Wenger, 2008). Secondly, that collaboration between isles of innovation is the precondition for larger societal transformations, yet the horizontal and dispersed learning processes required for such transformation are easily drowned by universal, top-down governance and corporate management practices (Duguid, 2008; Helfrich \& Bollier, 2019; Snyder \& Wenger, 2010). If these premises hold any truth, they are certainly worth further explorations with rigorous analysis in future research.

\section{Acknowledgments}

The author thanks the two reviewers for their constructive comments and the Ph.D. supervisor, Thilo Lang, for support throughout the work.

\section{References}

Amin, A., Cameron, A., \& Hudson, R. (2002). Placing the Social Economy. London, UK: Routledge. https://doi.org/10.4324/9780203166123

Amin, A., \& Roberts, J. (2008). Knowing in action: Beyond communities of practice. Research Policy, 37(2), 353-369. https://doi.org/10.1016/j. respol.2007.11.003

Bachnik, K., \& Szumniak-Samolej, J. (2017). Social initiatives in food consumption and distribution as part of sustainable consumption and sharing economy. Journal of Entrepreneurship, Management, and Innovation, 14(2), 101-122. https://doi.org/10.7341/20181425

Bacq, S., \& Janssen, F. (2011). The multiple faces of social entrepreneurship: A review of definitional issues based on geographical and thematic criteria. Entrepreneurship \& Regional Development, 23(5-6), 373-403. https://doi.org/10.1080/08985626.2011.577242

Barinaga, E. (2013). Politicising social entrepreneurship - Three social entrepreneurial rationalities toward social change. Journal of Social Entrepreneurship, 4(3), 347-372. http://dx.doi.org/10.1080/19420676. 2013.823100

Bauer, C. M., Guzmán, C., \& Santos, F.J. (2012). Social capital as a distinctive feature of social economy firms. International Entrepreneurship and Management Journal, 8(4), 437-448. https://doi.org/10.1007/s11365-012-0230-7

Becker, S., Kunze, C., \& Vancea, M. (2017). Community energy and social entrepreneurship: Addressing purpose, organisation and embeddedness of renewable energy projects. Journal of Cleaner Production, 147, 25-36. https://doi.org/10.1016/j.jclepro.2017.01.048

Bendt, P., Barthel, S., \& Colding, J. (2013). Civic greening and environmental learning in public-access community gardens in Berlin. Landscape 
and Urban Planning, 109(1), 18-30. https://doi.org/10.1016/j. landurbplan.2012.10.003

Blackmore, C. (Ed.). (2010). Social Learning Systems and Communities of Practice. London, UK: Springer. https://doi.org/10.1007/978-1-84996-133-2

Borzaga, C., \& Galera, G. (2016). Innovating the provision of welfare services through collective action: The case of Italian social cooperatives. International Review of Sociology, 26(1), 31-47. https://doi.org/10.1080 /03906701.2016.1148336

Bradbury, S., \& Middlemiss, L. (2015). The role of learning in sustainable communities of practice. Local Environment, 20(7), 796-810. https:// doi.org/10.1080/13549839.2013.872091

Brown, J. S., \& Duguid, P. (2001). Knowledge and organization: A socialpractice perspective. Organization Science, 12(2), 198-213. https://doi. org/10.1287/orsc.12.2.198.10116

Cho, A. H. (2008). Politics, values and social entrepreneurship: A critical appraisal. In J. Mair, J. A. Robinson, \& K. Hockerts (Eds.), Social Entrepreneurship (pp. 34-56). New York, N. Y: Palgrave Macmillan. https://doi.org/10.1057/9780230625655

Christmann, G. B. (2014). Social entrepreneurs on the periphery: Uncovering emerging pioneers of regional development. The Planning Review, 50(1), 43-55. https://doi.org/10.1080/02513625.2014.926725

Contu, A., \& Willmott, H. (2003). Re-embedding situatedness: The importance of power relations in learning theory. Organization Science, 14(3), 283296. https://doi.org/10.1287/orsc.14.3.283.15167

Dacin, P. A., Dacin, M. T., \& Matear, M. (2010). Social entrepreneurship: Why we don't need a new theory and how we move forward from here. Academy of Management Perspectives, 24(3), 37-57. https://doi. org/10.5465/amp.24.3.37

Dart, R. (2004). The legitimacy of social enterprise. Nonprofit Management and Leadership, 14(4), 411-424. https://doi.org/10.1002/nml.43

de Beer, M. (2018). Local social value creation by neighborhood-based entrepreneurs: Local embeddedness and the role of social networks. Social Enterprise Journal, 14(4), 450-469. https://doi.org/10.1108/SEJ-01-2018-0005

de Bruin, A., Shaw, E., \& Lewis, K. V. (2017). The collaborative dynamic in social entrepreneurship. Entrepreneurship \& Regional Development, 29(7-8), 575-585. https://doi.org/10.1080/08985626.2017.1328902

Dedeurwaerdere, T., De Schutter, O., Hudon, M., Mathijs, E., Annaert, B., Avermaete, T., Bleeckx, T., de Callataÿ, C., De Snijder, P., FernándezWulff, P., Joachain, H., \& Vivero, J.-L. (2017). The governance features of social enterprise and social network activities of collective food buying groups. Ecological Economics, 140, 123-135. https://doi.org/10.1016/j. ecolecon.2017.04.018

Dey, P., \& Steyaert, C. (2012). Social entrepreneurship: Critique and the radical enactment of the social. Social Enterprise Journal, 8(2), 90-107. https:// doi.org/10.1108/17508611211252828 
Dey, P., \& Teasdale, S. (2016). The tactical mimicry of social enterprise strategies: Acting 'as if' in the everyday life of third sector organizations. Organization, 23(4), 485-504. https://doi.org/10.1177/1350508415570689

Dufays, F., \& Huybrechts, B. (2014). Connecting the dots for social value: A review on social networks and social entrepreneurship. Journal of Social Entrepreneurship, 5(2), 214-237. https://doi.org/10.1080/19420 676.2014 .918052

Duguid, P. (2008). 'The art of knowing': Social and tacit dimensions of knowledge and the limits of the community of practice. In A. Ash \& J. Roberts (Eds.), Community, Economic Creativity and Organisation. (pp. 69-89). Oxford, UK and New York, NY: Oxford University Press. https:// doi.org/10.1093/acprof:oso/9780199545490.001.0001

Dunham, L. C. (2010). From rational to wise action: Recasting our theories of entrepreneurship. Journal of Business Ethics, 92(4), 513-530. https:// doi.org/10.1007/s10551-009-0170-5

Figueiredo, V., \& Franco, M. (2018). Wine cooperatives as a form of social entrepreneurship: Empirical evidence about their impact on society. Land Use Policy, 79, 812-821. https://doi.org/10.1016/j. landusepol.2018.09.022

Forster, F., \& Grichnik, D. (2013). Social entrepreneurial intention formation of corporate volunteers. Journal of Social Entrepreneurship, 4(2), 153181. https://doi.org/10.1080/19420676.2013.777358

Füg, F., \& Ibert, O. (2019). Assembling social innovations in emergent professional communities. The case of learning region policies in Germany. European Planning Studies, 28(3), 541-562. https://doi.org/1 $0.1080 / 09654313.2019 .1639402$

George, C., \& Reed, M. G. (2016). Building institutional capacity for environmental governance through social entrepreneurship: Lessons from Canadian biosphere reserves. Ecology and Society, 21(1). https:// doi.org/10.5751/ES-08229-210118

Gibson-Graham, J. K. (2006). Postcapitalist Politics. Minneapolis, MN: University of Minnesota Press. https://www.upress.umn.edu/bookdivision/books/a-postcapitalist-politics

Haugh, H. (2007). Community-led social venture creation. Entrepreneurship Theory and Practice, 31(2), 161-182. https://doi.org/10.1111/j.15406520.2007.00168.x

Helfrich, S., \& Bollier, D. (2019). Frei, Fair und Lebendig - Die Macht der Commons. Bielefeld, Germany: Transcript Verlag. https://doi. org $/ 10.14361 / 9783839445303$

Houtbeckers, E. (2017a). The everyday experiences of a sustainable entrepreneur: Brokering for social innovation at the intersection of networks of practice. In K. Nicolopoulou, M. Karataş-Özkan, \& F. Janssen (Eds.), Sustainable Entrepreneurship and Social Innovation. London, UK and New York, NY: Routledge. 
Houtbeckers, E. (2017b). Researcher subjectivity in social entrepreneurship ethnographies: The entanglement of stories in a co-working cooperative for social innovation. Social Enterprise Journal, 13(2), 128-143. https:// doi.org/10.1108/SEJ-07-2016-0025

Huybrechts, B., \& Nicholls, A. (2013). The role of legitimacy in social enterprise-corporate collaboration. Social Enterprise Journal, 9(2), 130146. https://doi.org/10.1108/SEJ-01-2013-0002

Huybrechts, B., Nicholls, A., \& Edinger, K. (2017). Sacred alliance or pact with the devil? How and why social enterprises collaborate with mainstream businesses in the fair trade sector. Entrepreneurship \& Regional Development, 29(7-8), 586-608. https://doi.org/10.1080/08985626.2017.1328905

Imperatori, B., \& Ruta, D. C. (2015). Designing a social enterprise. Social Enterprise Journal, 11(3), 321-346. https://doi.org/10.1108/SEJ-08-2014-0034

Jack, S. L., \& Anderson, A. R. (2002). The effects of embeddedness on the entrepreneurial process. Journal of Business Venturing, 17(5), 467-487. https://doi.org/10.1016/S0883-9026(01)00076-3

Jenner, P. (2016). Social enterprise sustainability revisited: An international perspective. Social Enterprise Journal, 12(1), 42-60. https://doi. org/10.1108/SEJ-12-2014-0042

Kasabov, E. (2016). Investigating difficulties and failure in early-stage rural cooperatives through a social capital lens. European Urban and Regional Studies, 23(4), 895-916. https://doi.org/10.1177/0969776415587121

Kimmitt, J., \& Muñoz, P. (2018). Sensemaking the 'social' in social entrepreneurship. International Small Business Journal: Researching Entrepreneurship, 36(8), 859-886. https://doi. org/10.1177/0266242618789230

Kwong, C., Tasavori, M., \& Wun-mei Cheung, C. (2017). Bricolage, collaboration and mission drift in social enterprises. Entrepreneurship \& Regional Development, 29(7-8), 609-638. https://doi.org/10.1080/08985626.20 17.1328904

Laratta, R. (2009). Autonomy and accountability in social services nonprofits: Japan and UK. Social Enterprise Journal, 5(3), 259-281. https://doi. org/10.1108/17508610911004331

Lave, J., \& Wenger, E. (1991). Situated Learning: Legitimate Peripheral Participation. New York, NY: Cambridge University Press. https://doi. org/10.1017/CBO9780511815355

Lewis, D. (2017). Should we pay more attention to south-north learning? Human Service Organizations: Management, Leadership \& Governance, 41(4), 327-331. https://doi.org/10.1080/23303131.2017.1366222

Littlewood, D., \& Khan, Z. (2018). Insights from a systematic review of literature on social enterprise and networks: Where, how and what next? Social Enterprise Journal, 14(4), 390-409. https://doi.org/10.1108/SEJ11-2018-068 
Mair, J., \& Martí, I. (2006). Social entrepreneurship research: A source of explanation, prediction, and delight. Journal of World Business, 41(1), 36-44. https://doi.org/10.1016/j.jwb.2005.09.002

Mauksch, S. (2012). Beyond managerial rationality: Exploring social enterprise in Germany. Social Enterprise Journal, 8(2), 156-170. https:// doi.org/10.1108/17508611211252864

McRobbie, A. (2013). Fashion matters Berlin; city-spaces, women's working lives, new social enterprise? Cultural Studies, 27(6), 982-1010. https:// doi.org/10.1080/09502386.2012.733171

Meyer, M., Maier, F., Ferrarini, A., Filho, G. C., Gaiger, L. I., Hillenkamp, I., Kitajima, K., Laville, J.-L., Lemaître, A., Sadik, Y., Veronese, M., \& Wanderley, F. (2015). The future of civil society organization governance: Beyond managerialism. In J.-L. Laville, D. R. Young, \& P. Eynaud (Eds.), Civil Society, the Third Sector and Social Enterprise: Governance and Democracy (pp. 45-57). London, UK and New York, NY: Routledge.

Mitzinneck, B. C., \& Besharov, M. L. (2018). Managing value tensions in collective social entrepreneurship: The role of temporal, structural, and collaborative compromise. Journal of Business Ethics, 159, 381-400. https://doi.org/10.1007/s10551-018-4048-2

Montgomery, A. W., Dacin, P. A., \& Dacin, M. T. (2012). Collective social entrepreneurship: Collaboratively shaping social good. Journal of Business Ethics, 111(3), 375-388. https://doi.org/10.1007/s10551-012-1501-5

Muñoz, S.-A. (2010). Towards a geographical research agenda for social enterprise. Area, 42(3), 302-312. https://doi.org/10.1111/j.1475-4762.2009.00926.x

Newth, J. (2016). Social Enterprise innovation in context: Stakeholder influence through contestation. Entrepreneurship Research Journal, 6(4), 369-399. https://doi.org/10.1515/erj-2014-0029

Nicholls, A. (Ed.). (2006). Social Entrepreneurship: New Models of Sustainable Social Change. New York NY: Oxford University Press. https://dhriiti.com/ wp-content/uploads/2018/01/Social-Entrepreneurship-New-Models-ofSustainable-Social-Change.pdf

Nyssens, M., \& Petrella, F. (2015). The social and solidarity economy and Ostrom's approach to common pool resources. Towards a better understanding of institutional diversity. In J.-L. Laville, D. R. Young, \& P. Eynaud (Eds.), Civil Society, the Third Sector and Social Enterprise: Governance and Democracy (pp. 178-190). London, UK and New York, NY: Routledge.

Olinsson, S. B. (2017). Social entrepreneurship-Committing theory to practice. Journal of Social Entrepreneurship, 8(2), 225-247. https://doi.org/10.10 80/19420676.2017.1375547

Oreszczyn, S., Lane, A., \& Carr, S. (2010). The role of networks of practice and webs of influencers on farmers' engagement with and learning about agricultural innovations. Journal of Rural Studies, 26(4), 404-417. https://doi.org/10.1016/j.jrurstud.2010.03.003

Pais, C. A., \& Parente, C. (2015). Representations of team work among organizations with a social entrepreneurship profile: A multiple case- 
study. Team Performance Management: An International Journal, 21(1/2), 65-84. https://doi.org/10.1108/TPM-07-2014-0042

Petticrew, M., \& Roberts, H. (2006). Systematic Reviews in the Social Sciences: A Practical Guide. Malden, MA: Blackwell. https://www.wiley.com/ en-us/Systematic+Reviews+in+the+Social+Sciences\%3A+A+Practical +Guide-p-9781405121101

Picciotti, A. (2017). Towards sustainability: The innovation paths of social enterprise. Annals of Public and Cooperative Economics, 88(2), 233256. https://doi.org/10.1111/apce.12168

Pret, T., \& Carter, S. (2017). The importance of 'fitting in': Collaboration and social value creation in response to community norms and expectations. Entrepreneurship \& Regional Development, 29(7-8), 639-667. https://doi.org/10.1080/08985626.2017.1328903

Richter, R. (2017). Rural social enterprises as embedded intermediaries: The innovative power of connecting rural communities with supra-regional networks. Journal of Rural Studies, 70, 179-187. https://doi. org/10.1016/j.jrurstud.2017.12.005

Richter, R. (2018). The Janus face of participatory governance: How inclusive governance benefits and limits the social innovativeness of social enterprises. The Journal of Entrepreneurial and Organizational Diversity, 7(1), 61-87. https://doi.org/10.5947/jeod.2018.004

Ridley-Duff, R. (2009). Co-operative social enterprises: Company rules, access to finance and management practice. Social Enterprise Journal, 5(1), 50-68. https://doi.org/10.1108/17508610910956408

Roberts, J. (2006). Limits to communities of practice. Journal of Management Studies, 43(3), 623-639. https://doi.org/10.1111/j.14676486.2006.00618.x

Rossignoli, C., Ricciardi, F., \& Bonomi, S. (2018). Organizing for commons-enabling decision-making under conflicting institutional logics in social entrepreneurship. Group Decision and Negotiation, 27(3), 417-443. https://doi.org/10.1007/s10726-018-9564-z

Salemink, K., Strijker, D., \& Bosworth, G. (2017). The community reclaims control? Learning experiences from rural broadband initiatives in the Netherlands. Sociologia Ruralis, 57, 555-575. https://doi. org/10.1111/soru.12150

Shaw, E., \& Carter, S. (2007). Social entrepreneurship: Theoretical antecedents and empirical analysis of entrepreneurial processes and outcomes. Journal of Small Business and Enterprise Development, 14(3), 418-434. https://doi.org/10.1108/14626000710773529

Smeets, D. J. A. (2017). Collaborative learning processes in social impact bonds: A case study from the Netherlands. Journal of Social Entrepreneurship, 8(1), 67-87. https://doi.org/10.1080/19420676.2017.1299034

Snyder, W. M., \& Wenger, E. (2010). Our world as a learning system: A communities-of-practice approach. In C. Blackmore (Ed.), Social Learning Systems and Communities of Practice (pp. 107-124). London, UK: 
Springer. https://doi.org/10.1007/978-1-84996-133-2_7

Sonnino, R., \& Griggs-Trevarthen, C. (2013). A resilient social economy? Insights from the community food sector in the UK. Entrepreneurship \& Regional Development, 25(3-4), 272-292. https://doi.org/10.1080 /08985626.2012.710268

Steinerowski, A. A., \& Steinerowska-Streb, I. (2012). Can social enterprise contribute to creating sustainable rural communities? Using the lens of structuration theory to analyse the emergence of rural social enterprise. Local Economy, 27(2), 167-182. https://doi. org/10.1177/0269094211429650

Stubbs, P., \& Vidović, D. (2017). Social Enterprise in transition: A case study of ACT group. Drustvena Istrazivanja, 26(2), 143-163. https://doi. org/10.5559/di.26.2.01

Tandon, A. (2014). Investigating learning in social enterprises: A boundary perspective. Social Enterprise Journal, 10(2), 155-172. https://doi. org/10.1108/SEJ-05-2013-0022

Thompson, J. L. (2008). Social enterprise and social entrepreneurship: Where have we reached? A summary of issues and discussion points. Social Enterprise Journal, 4(2), 149-161. https://doi. org/10.1108/17508610810902039

Tracey, P., Phillips, N., \& Haugh, H. (2005). Beyond philanthropy: Community enterprise as a basis for corporate citizenship. Journal of Business Ethics, 58(4), 327-344. https://doi.org/10.1007/s10551-004-6944-x

Tregear, A. (2011). Progressing knowledge in alternative and local food networks: Critical reflections and a research agenda. Journal of Rural Studies, 27(4), 419-430. https://doi.org/10.1016/j.jrurstud.2011.06.003

Utting, P. (2015). Introduction: The challenge of scaling up social and solidarity economy. In P. Utting (Ed.), Social and Solidarity Economy: Beyond the Fringe (pp. 1-37). London, UK: Zed Books. http://www.unrisd. org/80256B3C005BCCF9/(httpPublications)/89748F9EB30DE128C1 257E0E004889D4

van der Horst, D. (2008). Social enterprise and renewable energy: Emerging initiatives and communities of practice. Social Enterprise Journal, 4(3), 171-185. https://doi.org/10.1108/17508610810922686

Velvin, J., Bjørnstad, K., \& Krogh, E. (2016). Social value change, embeddedness and social entrepreneurship. Journal of Enterprising Communities: People and Places in the Global Economy, 10(3), 262-280. https://doi.org/10.1108/JEC-08-2014-0015

Vestrum, I. (2014). The embedding process of community ventures: Creating a music festival in a rural community. Entrepreneurship \& Regional Development, 26(7-8), 619-644. https://doi.org/10.1080/08985626 .2014.971076

Wenger, E. (2008). Communities of Practice: Learning, Meaning, and Identity (16th pr). New York, NY: Cambridge University Press. https://doi. org/10.1017/CBO9780511803932 
Woods, M. (2007). Engaging the global countryside: Globalization, hybridity and the reconstitution of rural place. Progress in Human Geography, 31(4), 485-507. https://doi.org/10.1177/0309132507079503

Wynne-Jones, S. (2017). Understanding farmer co-operation: Exploring practices of social relatedness and emergent affects. Journal of Rural Studies, 53, 259-268. https://doi.org/10.1016/j.jrurstud.2017.02.012

\begin{abstract}
Abstrakt
Cel: Celem tego artykułu jest, po pierwsze, zbadanie i ustrukturyzowanie pojawiajacych się badań nad współpraca w przedsiębiorczości społecznej, a po drugie zajęcie się zidentyfikowanymi lukami w literaturze za pomoca programu badawczego opartego na społeczności i sieciach teorii praktyki. Metodyka: Artykuł opiera się na systematycznym przeglqqdzie literatury, który podsumowuje istniejqcą bazę dowodów i krytycznie ocenia główne podejścia teoretyczne. Analiza skupia się na niejednoznaczności i skali współpracy. Wyniki: Zidentyfikowano trzy główne wqtki badawcze: po pierwsze, współpraca społeczności i sektora publicznego skupiajq̨ca się na partycypacyjnym inicjowaniu usług przez społeczności lokalne; po drugie, współpraca w zakresie zasobów i zatrudnienia skupiajq̨ca się na stosunkach władzy między ustanowionymi organizacjami; i po trzecie, współpraca na poziomie sieci i mikro, skupiajq̨ca się na wspólnym zarzq̨dzaniu złożonymi sieciami. Dominuje niejasno kontekstualizowane i niekrytyczne podejście do przedsiębiorczości społecznej; Jednak ostatnie badania dotyczqce współpracy społeczności i sieci przedstawiajq pewne niuanse podejścia do skalarności i niejednoznaczności. Implikacje dla teorii i praktyki: Istniejqce badania mogłyby odnieść korzyści z jawnej i szerszej teorii współpracy, z analizy niejednoznacznych doświadczeń i kontekstów oraz zajęcia się wzajemnym oddziaływaniem między codziennymi praktykami a zmianami instytucjonalnymi na większq skalę. Artykuł przedstawia skompilowanq bazę referencyjnq i daje wskazówki dotyczq̨e przyszłych badań i praktyki ponownego przemyślenia przedsiębiorstwa społecznego jako przedsięwzięcia opartego na współpracy. Oryginalność i wartość: Artykuł wnosi wkład do badań nad przedsiębiorczościq społecznq poprzez uporzqdkowanie dziedziny i wzmocnienie krytycznej teorii na ten temat.
\end{abstract}

Słowa kluczowe: przedsiębiorczość społeczna, przedsiębiorstwo społeczne, współpraca, wspólnoty praktyk, sieci praktyk.

\title{
Biographical note
}

Sunna Kovanen is a researcher at the Leibniz-Institute for Regional Geography, Leipzig, and a Ph.D. candidate at the University of Leipzig. She has conducted the research within the Marie-Curie ITN-project RurAction, GA 721999 on Social Entrepreneurship in Structurally Weak Rural Regions.

\section{Conflicts of interest}

The author declares no conflict of interest. 


\section{Citation (APA Style)}

Kovanen,S.(2021).Socialentrepreneurshipasacollaborativepractice:Literature review and research agenda. Journal of Entrepreneurship, Management and Innovation, 17(1), 97-128. https://doi.org/10.7341/20211713 